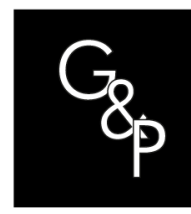

\title{
Satisfaction of professionals of participating companies with the performance of supplier development programs
}

\section{A satisfação dos profissionais das empresas participantes com a atuação de programas de desenvolvimento de fornecedores}

\author{
Carlos Jorge Taborda Macedo ${ }^{1,2}$ (D), Emerson Wagner Mainardes ${ }^{3}$ (D), \\ Amilson de Araújo Durans ${ }^{1,2,4}$ (D) \\ ${ }^{1}$ Fucape Business School, São Luis, MA, Brasil. E-mail: carlosjorge@fiema.org.br; amilsondurans@fiema.org.br \\ ${ }^{2}$ Sistema FIEMA, São Luís, MA, Brasil. E-mail: carlosjorge@fiema.org.br; amilsondurans@fiema.org.br \\ ${ }^{3}$ Fucape Business School, Vitória, ES, Brasil. E-mail: emerson@fucape.br \\ ${ }^{4}$ Faculdade Santa Terezinha - CEST, São Luís, MA, Brasil. E-mail: amilsondurans@fiema.org.br
}

How to cite: Macedo, C. J. T., Mainardes, E. W., \& Durans, A. A. (2021). Satisfaction of professionals of participating companies with the performance of supplier development programs. Gestão \& Produção, 28(2), e5241. https://doi.org/10.1590/1806-9649-2020v28e5241

\begin{abstract}
With the aim of demonstrating the elements that lead to the satisfaction of the professionals of participating companies with the performance of the Supplier Development Programs - SDPs, something that can improve the performance of this type of program, this research aimed to identify if the trust, in its affective, behavioral and cognitive components, influences the commitment and the perception of less risks, leading, consequently, to the satisfaction of the professionals of participating companies with the performance of the SDPs to which they are linked. Based on studies involving all the analyzed constructs, relationships between them were suggested and a structural model was proposed associating them. A quantitative, descriptive and cross-sectional study was carried out involving professionals from buyers and suppliers that participate in SDPs from all over Brazil, obtaining a sample, characterized as non-probabilistic and by accessibility, of 609 respondents from the application of a self-administered electronic questionnaire. For the analysis of the data, the modeling of structural equations was used, which indicated a positive relation for almost all the hypotheses, with only one being rejected. The findings suggest that reinforcing trust, mainly behavioral and cognitive, can increase the commitment of companies to the actions developed by the SDPs to which they are linked, as well as generate the perception that there are fewer risks when transacting with companies also linked to these programs, resulting in the satisfaction of buyers and suppliers. This may result in better program efficiency and effectiveness, and this is a contribution of this study, by identifying what leads participants to SDPs to be satisfied.
\end{abstract}

Keywords: Supplier Development Programs; Satisfaction; Commitment; Perception of risk; Trust.

Received Jan. 28, 2019 - Accepted June 10, 2019

Financial support: Brazilian National Council for Scientific and Technological Development (CNPq/Brazil), project 304209/2018-0, Foundation for Research Support of Espírito Santo (FAPES/Brazil), projects 84513772 (599/2018) and 85395650 (228/2019), Portuguese Science Foundation (FCT/Portugal) through NECE (Núcleo de Estudos em Ciências Empresariais), project UID/GES/04630/2020 and IFTS (Instituto Fucape de Tecnologias Sociais), project 2021-2024. This research had the collaboration of the Federation of Industries of the State of Maranhão-FIEMA and the Program for the Development of Suppliers of Maranhão-PDF. 
Resumo: Vislumbrando demonstrar os elementos que levam à satisfação dos profissionais de empresas participantes com a atuação dos Programas de Desenvolvimento de Fornecedores PDFs, algo que pode melhorar o desempenho deste tipo de programa, esta pesquisa objetivou identificar se a confiança, nas suas componentes afetiva, comportamental e cognitiva, influencia o comprometimento e a percepção de menos riscos, levando, por consequência, à satisfação dos profissionais de empresas participantes com a atuação dos PDFs a que estão vinculadas. Com base em estudos envolvendo todos os construtos analisados, foram sugeridas relações entre eles e foi proposto um modelo estrutural associando-os. Realizou-se uma pesquisa quantitativa, descritiva e com corte transversal envolvendo profissionais de empresas compradoras e fornecedoras que participam de PDFs de todo o Brasil, obtendo-se uma amostra, caracterizada como não probabilística e por acessibilidade, de 609 respondentes a partir da aplicação de um questionário eletrônico autoadministrado. Para análise dos dados, empregouse a modelagem de equações estruturais, que indicou relação positiva para quase todas as hipóteses, sendo apenas uma rejeitada. Os achados sugerem que reforçar a confiança, principalmente comportamental e cognitiva, pode proporcionar elevação do comprometimento das empresas com as ações desenvolvidas pelos PDFs a que estão vinculadas, bem como gerar a percepção de que há menos riscos ao transacionar com empresas também vinculadas a esses programas, resultando na satisfação de empresas compradoras e fornecedoras. Isto pode resultar em melhor eficiência e eficácia dos programas, sendo esta uma contribuição deste estudo, ao identificar o que leva os participantes dos PDFs a ficarem satisfeitos.

Palavras-chave: Programas de Desenvolvimento de Fornecedores; Satisfação; Comprometimento; Percepção de risco; Confiança.

\section{Introduction}

Managers in general have already realized that the performance of suppliers has a direct impact on the performance of companies, affecting the way they meet the needs of their customers (Botelho \& Bourguignon, 2011; Viana \& Alencar, 2012). They also realized that critical analysis of suppliers increases the quality of products and services provided (Capioto et al., 2019). These findings have intensified the search for qualified suppliers capable of meeting the requirements of the contracting companies (Viana \& Alencar, 2012), such as quality requirements, health and safety at work and production, social and environmental responsibility (Freitas, 2009; Yawar \& Seuring, 2018).

The narrowing and maintenance of the relationship between buyer companies and their suppliers have already been flagged as essential factors for the competitiveness of companies (Cambra-Fierro \& Polo-Redondo, 2008; Nagati \& Rebolledo, 2013; Yawar \& Seuring, 2018), being considered one of the most important aspects for the success of the companies (Gonçalo \& Alencar, 2014). This perception has led an increasing number of companies to act, directly or indirectly, in the development of their suppliers (Botelho \& Bourguignon, 2011; Nagati \& Rebolledo, 2013) as a means of ensuring that these companies meet the contractor's supply requirements (Freitas, 2009).

With the purpose of acting in the qualification of suppliers located in regions where large industrial enterprises are installed and stimulate commercial transactions between these companies, which are relevant buyers, and local suppliers, in several Brazilian states, developments known generically as Supplier Development Programs or SDPs were created (Freitas, 2009; Botelho \& Bourguignon, 2011). The execution of qualification and incentive actions to form business links is only possible if there is trust (Yawar \& Seuring, 2018), generating compromise and minimizing the risks in 
commercial transactions between buying and supplying companies (Marconatto, Estivalete, \& Pedrozo, 2014).

Therefore, trust, commitment and the mitigation of the risks involved tend to be related to the level of satisfaction in commercial relations (Viana et al., 1999; Marconatto et al., 2014). On the other hand, despite the assumption of the influence of trust, the perception of less risks and commitment on satisfaction, we observed that these influence relationships were not verified empirically in a business-to-business environment, and this is the knowledge gap dealt with here.

Given the above, it can be assumed that trust, in its affective, behavioral and cognitive components (Terres et al., 2009), deposited by professionals related to the supply process (managers, buyers and suppliers) both the buyer and the suppliers companies in the performance of the Supplier Development Programs to which they are linked. And this may influence the perception of these companies that there are fewer risks involved in established business relationships with companies associated with SDPs, as well as influence their commitment to such programs (Viana et al., 1999; Hor-Meyll, 2004; Marconatto et al., 2014).

And these factors, perception of less risk and commitment, may be associated with satisfaction with the performance of these programs, which is presumed to be a relevant element of SDPs to leverage business opportunities between purchasing and supplying companies (Beitelspacher et al., 2018; Devlin et al., 2018). Thus, the question that motivated this research was: Does trust, in its affective, behavioral and cognitive components, influences the commitment and the perception of less risks, leading, consequently, to the satisfaction of the professionals of participating companies with the performance of the SDPs to which they are linked?

To answer this question, we first analyzed studies covering the mentioned constructs. From this analysis we suggest relationships between the constructs, for which we formulate hypotheses, and a structural model was proposed associating trust, in its affective, behavioral and cognitive components, to the commitment and perception of less risks and these two, in turn, associated with the satisfaction of the professionals of buyers and suppliers with the performance of the SDPs to which they are linked.

Then we conducted a survey involving professionals from purchasing companies and suppliers that participate in programs all over Brazil, obtaining a sample of 609 respondents from the application of a questionnaire. For the analysis of the data, the modeling of structural equations was used. After the statistical analysis of the data, the results indicated a positive relation for almost all the hypotheses, with only one being rejected. This led to the conclusion that reinforcing trust, mainly behavioral and cognitive, can increase the commitment of the companies with the actions developed by the SDPs to which they are linked, as well as generating the perception that there are fewer risks when transacting with companies also linked to these programs, resulting in satisfaction on the part of purchasing companies and suppliers.

In the field of theoretical contribution, this study analyzes trust in its affective, behavioral and cognitive components (Terres et al., 2009), as antecedent element of the commitment (Viana et al., 1999) and the perception of less risks (Hor-Meyll, 2004). These last two factors may be possible influencers of satisfaction (Rauyruen \& Miller, 2007; Cambra-Fierro \& Polo-Redondo, 2008; Caroço \& Correia, 2012) of professionals from buyer and supplier companies from all over Brazil with the performance of the Supplier Development Programs to which they are linked, collaborating with the knowledge about the process that leads to satisfaction in the supply chain. It should be 
noted that such constructs, trust, commitment, perception of less risk and satisfaction, which are usually investigated in business-to-consumer relations, were employed in this study, in a related way, in business-to-business interactions, with SDPs being attributed the role of service providers and purchasing and supplying companies the role of consumers (Sirdeshmukh et al., 2002).

According to the National Confederation of Industry (CNI, 2017), the Supplier Development Programs that operate in the industrial segment, in the year 2016 alone, served more than 40 large purchasing industries and qualified over 500 suppliers in 17 Brazilian states. Given these numbers and considering the role of SDPs in the business environment, as a practical contribution, we hope that this research will demonstrate to Brazilian programs how trust, commitment and perception of fewer risks influence the satisfaction of professionals of buying and supply companies with the actions that these programs develop. This enables improving the efficiency and effectiveness of SDPs, by identifying what drives program participants to be satisfied, influencing the permanence of buyers and suppliers linked to such programs, benefiting the entire business environment and, as a consequence, society.

\section{Theoretical framework}

Since the mid-1990s, movements known generically as Supplier Development Programs or SDPs have been created in several states in Brazil. Such programs promote interaction between buying companies and their suppliers (Freitas, 2009; Botelho \& Bourguignon, 2011), stimulating business generation through the development of supplier companies, this being a relevant issue, since a buyer is more likely to contact a supplier the higher their institutional quality (Lanzolla \& Frankort, 2016).

These SDPs are maintained financially by large industrial companies, which are important buyers of diverse materials and services, and are primarily intended to qualify current and potential suppliers located in regions where such industries are installed, stimulating commercial transactions between these companies (Freitas, 2009; Botelho \& Bourguignon, 2011). In the Brazilian scenario, the SDPs of three states stand out for the time of existence (Freitas, 2009): Espírito Santo, Maranhão and Pará, with the first State being the precursor. In other units of the federation there have also been actions of development of suppliers, mostly carried out by state industry federations ( $\mathrm{CNI}$, 2017), as is the case with the programs of Espírito Santo, Maranhão and Pará.

Promoting the development of local suppliers is a strategy that seeks to align buying companies and supplying companies, resulting in the establishment of business links, ultimate goal of SDPs. To make this development feasible, the SDPs generally act in three vectors: business advisory; training and certification; promotion and dissemination (Freitas, 2009; Botelho \& Bourguignon, 2011).

In the business advisory vector, the performance of the SDPs is by prospecting business opportunities for local companies, resulting in its indication to the applicant company of suppliers of the region with capacity to meet its need. Other actions such as the realization of technical visits, business rounds and consultancies are also part of this vector (Freitas, 2009; Botelho \& Bourguignon, 2011).

To act in the vector training and certification, SDPs establish partnerships with entities with expertise in training actions, such as the Brazilian Micro and Small Business Support Service (Sebrae), the National Service of Industrial Learning (Senai), the Euvaldo Lodi Institute (IEL), among others. With regard to certification, the SDPs 
establish their own actions aimed at qualifying local suppliers in the supply requirements of the large buying industries and certify those that meet the established criteria. Examples of certification actions are: the Supplier Qualification Program (PQF), in Bahia; the Integrated Program for the Development and Qualification of Suppliers (Prodfor), in Espírito Santo; and the Business Certification Program (Procem), in Maranhão (Freitas, 2009; Botelho \& Bourguignon, 2011; CNI, 2017).

Finally, the promotion and disclosure vector aims to give visibility to the actions performed by the SDPs, valuing large buying industries financially maintaining the programs, partner entities and associated suppliers, as well as seeking to attract new buyers and suppliers. Each SDP acts more strongly in one of these vectors, according to the regional characteristics (Freitas, 2009; Botelho \& Bourguignon, 2011).

\section{Satisfaction with the SDP}

According to study by König \& Duarte (2014), in a commercial relationship, satisfaction is related to the degree to which the customer evaluates if they got what they wanted with the purchase of a product and/or service. In the literature, there is still evidence that satisfaction is a phenomenon triggered by the confirmation of expectations (Campos et al., 2015), that is, by the positive difference between the result and the expectation (König \& Duarte, 2014).

Rauyruen \& Miller (2007) conducted a study of 306 Australian small and mediumsized enterprises and demonstrated that the quality of the relationship can influence customer loyalty in the business-to-business context (B2B). In this study, the quality of the relationship between buyer and supplier was understood as a larger construct, including trust, commitment and satisfaction.

B2B interaction between buyer and supplier firms seems to influence buyer acquisition behaviors, which can positively affect supplier revenues, and vendor behaviors and capabilities, which can positively affect the productive processes and the results of the buyer, transforming this interaction into an element of satisfaction (Cambra-Fierro \& Polo-Redondo, 2008). In addition, the satisfaction of the service provider with its main client, in the business-to-business environment, generates a better performance (Borella et al., 2017).

Thus, it is considered that the satisfaction of professionals from buying and supplying companies with the performance of the SDP to which they are linked may be due to the good commercial relationships established with other companies also linked to the program, crediting the SDP to provide a good service to indicate attractive trading partners (Freitas, 2009). And evaluating the satisfaction of these professionals with the performance of the SDPs can generate useful information for the definition of strategies aimed at improving the quality of service delivery by the programs (Bortolotti et al., 2012).

\section{Commitment to the SDP}

Commitment is considered a central construct of relational behavior, which makes it evaluated as a key variable in successful relationship models between companies (Rauyruen \& Miller, 2007; Lancastre \& Lages, 2006), both buyers and suppliers (Kim \& Choi, 2015). High levels of commitment generate positive impacts on organizational results, leading to satisfaction and motivation (Caroço \& Correia, 2012). In this context, 
organizations can invest in factors that encourage commitment, since the development and maintenance of business relationships between companies requires long-term commitment and trust (Viana et al., 1999).

The commitment results, for suppliers, in greater access to market information for the creation or improvement of products/services and, for buyers, in access to more relevant information on delivery times and product characteristics, as well as more efficient provision of services (Lancastre \& Lages, 2006). As suppliers and buyers gain access to valuable information from the other party, each partner develops a motivation to build, maintain and strengthen the relationship, making them more likely to perceive their relationship as win-win (Kim \& Choi, 2015).

In this research we adopted the construct commitment (Viana et al., 1999) to evaluate the level of involvement and commitment of buying and supplying companies with the Supplier Development Programs, based on a historical perspective of the relationship with these programs. It is believed that the more committed the professionals of these companies are with the actions of the SDPs, the more satisfied they will be with the performance of the programs, motivating companies to perpetuate their bond (Borella et al., 2017)

\section{Perception of less risks}

This research evaluated the perception of the professionals of buying and supplying companies regarding the risks involved in the commercial transactions carried out with companies linked to the Supplier Development Programs, based on the total risk construct extracted from Hor-Meyll (2004), which measures the perception of risk in a generic way, without specifying a type of risk. According to the author, the perception of risk is due to the evaluation of a given situation and from this assessment subjectively infer an expectation of loss, that is, the risk involved.

In this sense, the mitigation of the risk element shows itself to be a strategy of competitive advantage by enabling security to commercial transactions between companies (Shi et al., 2018). By reducing the perceived risks in business relationships between supply chain partners, future transactions and investments are encouraged (Beitelspacher et al., 2018), which reinforces that risk is one of the elements of effect when choosing a contract (Devlin et al., 2018).

Considering that generating business opportunities is one of the premises of SDPs, which seek to insert local suppliers in the supply chains of large buying industries and stimulate commercial transactions between them (Freitas, 2009; Botelho \& Bourguignon, 2011), the perception that risks in business transactions can be mitigated by involving local firms linked to such programs, can be an influencing element of satisfaction with the performance of SDPs. From this analysis it is possible to consider that the perception that there are fewer risks involved in the commercial relations established with companies associated to the SDPs positively influences the satisfaction of the companies linked to the programs.

\section{Trust in SDP}

This study took into account for the trust construct the definition by Sirdeshmukh et al. (2002), which describes it as the consumer's expectation that the service provider is reliable and that it is possible to believe that they will deliver what 
they have promised. By analogy, we understand that the role of "consumer" lies with buying or supplying companies and that the role of "service provider" is the responsibility of the SDPs.

In this way, to the buying companies, the programs provide the qualification service of their suppliers. In addition to the supplier companies, besides providing the service of qualification - essence of its performance -, the SDPs provide the service of approximation of these with the buying companies, generating business opportunities (Freitas, 2009; Botelho \& Bourguignon, 2011). In this scenario, it can be deduced that the two main actors - buyers and suppliers - trust that SDPs will deliver what they promised.

Considering studies on the trust factor (Dowell et al., 2015; Skippari et al., 2017), this research evaluated the trust in the relations maintained by buyers and suppliers with the SDPs as antecedent element of the commitment of such organizations with these programs and the perception that there are fewer risks involved in commercial transactions between companies linked to them. For this purpose, the trust was evaluated through its components affective trust, behavioral trust and cognitive trust (Terres et al., 2009).

In B2B interactions, affective trust may surpass what is expected as the emotional bond widens. A sense of security and affective attachment reflects this reality, leading to promising involvement and a sense of security that positively impacts the interest in investing in this relationship (Akrout et al., 2016). In this way, the emotional bond generated by the affective trust that buyers and suppliers deposit in the SDPs can result in commitment to the performance of these programs. Therefore, it is possible to assume that affective trust positively influences the commitment of buying and supplying companies to SDPs.

In the case of SDPs, affective trust can motivate the feeling that programs are genuinely interested in business issues: search for qualified suppliers for buying companies and the need for development for supplier companies. This feeling may occur because the outcome of trust is defined by the belief of one company that the other will perform actions that will culminate in positive results for themselves, in addition to not taking unexpected actions that cause negative results (Cambra-Fierro \& Polo-Redondo, 2008; Marconatto et al., 2014).

Such feelings of security and genuine interest in business issues stemming from the affective trust that buyers and suppliers place in SDPs may influence the perception of these companies that there are fewer risks involved in the commercial relations established with other companies which are also linked to those programs and that they have indicated. From this perspective it can be considered that affective trust positively influences the perception that there are fewer risks involved in the commercial relations between companies linked to SDPs.

Regarding behavioral trust, Rauyruen \& Miller (2007) stress that understanding their nature and the importance of their contribution can impact on how companies develop and manage their B2B relationships. Trust is a central factor in the development of successful relationships in B2B markets (Rauyruen \& Miller, 2007), being fundamental to a strategic partnership (Lancastre \& Lages, 2006).

Relationships characterized by behavioral trust are highly valued and culminate in more desire for commitment, since it is a determining factor in the development of cooperative efforts and actions (Lancastre \& Lages, 2006). Therefore, it is assumed that behavioral trust can result in the commitment of buying and supplying companies to the performance of SDPs. Based on this understanding, it is considered that 
behavioral trust positively influences the commitment of buying and supplying companies with SDPs.

Behavioral trust can motivate buying and supplying companies to share information with the SDPs to which they are linked, because they believe they will use this information only to select good trading partners for both. Trust is a central building block for the development of successful relationships in B2B markets (Rauyruen \& Miller, 2007). This understanding may lead buyers and suppliers to believe that there are fewer risks involved in established business relationships with companies associated with SDPs. Thus, from this perspective, we can assume behavioral trust positively influences the perception that there are less risks involved in business relationships between companies linked to SDPs.

More than the other dimensions of trust, cognitive trust is based on the knowledge of the properties of the other part, derived from a relationship history (Terres et al., 2009), which can increase the quality and commitment of decision making in the supply chain (Parayitam \& Dooley, 2009; Narayanan \& Moritz, 2015). Assuming that cognitive trust can motivate collaboration in a B2B relationship, we can consider that the willingness to collaborate influences the commitment of those involved to reach positive results for all of this relationship.

Thus, a history of positive relationships coupled with the propensity of buying and supplying companies to collaborate with the SDPs may result in a commitment to the performance of these programs. From this understanding about cognitive trust, it is assumed that cognitive trust positively influences the commitment of buyers and suppliers with SDPs.

Still according to the study by Terres et al. (2009), in the cognitive dimension, the level of trust that buyers and suppliers have with respect to SDPs is based on the evaluation of questions as competence and responsibility deriving from the history of relationship with the programs. And the responsible action of SDPs to indicate good trading partners can influence the perception of buyers and suppliers that there are fewer risks involved in the established business relationships with companies associated with such programs. Thus, we can consider that cognitive trust positively influences the perception that there are fewer risks involved in the commercial relations between companies linked to SDPs.

\section{Methodology}

\subsection{Proposed model}

Based on the hypotheses elaborated, listed in Table 1, the model of this research was developed, which was based on the constructs trust (Terres et al., 2009), perception of the risks involved (Hor-Meyll, 2004) in commercial transactions carried out with companies linked to the SDPs, (Viana et al., 1999) with their performance and satisfaction (Larán \& Rossi, 2003) with such programs. According to the model presented in Figure 1, the factors commitment and the perception of less risks tend to influence satisfaction with the performance of SDPs, insofar as the more committed the company is and the less risk it perceives in commercial transactions with companies linked to the programs, more satisfied it should potentially be.

The model also shows that trust, in its affective, behavioral and cognitive components, influences the commitment and the perception of less risks. That is, the 
more trust placed on the performance of SDPs, the more committed companies will be and the less risk they will perceive when conducting business transactions with companies linked to these programs.

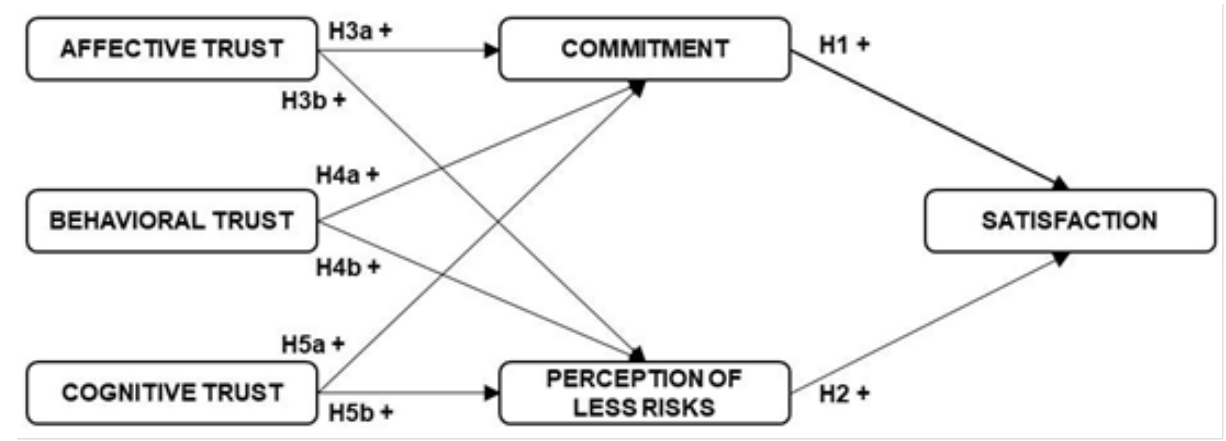

Figure 1. Proposed Model. Source: Authors' own elaboration.

Table 1. List of hypotheses.

\begin{tabular}{|c|c|}
\hline $\mathrm{H} 1$ & $\begin{array}{l}\text { The commitment to the actions of the SDPs positively influences the satisfaction of the } \\
\text { companies linked to the programs. }\end{array}$ \\
\hline $\mathrm{H} 2$ & $\begin{array}{l}\text { The perception that there are fewer risks involved in the commercial relations } \\
\text { established with companies associated to the SDPs positively influences the } \\
\text { satisfaction of the companies linked to the programs. }\end{array}$ \\
\hline $\mathrm{H} 3 \mathrm{a}$ & Affective trust positively influences the commitment of buyers and suppliers to SDPs. \\
\hline $\mathrm{H} 3 \mathrm{~b}$ & $\begin{array}{l}\text { Affective trust positively influences the perception that there are fewer risks involved in } \\
\text { business relationships between companies linked to SDPs. }\end{array}$ \\
\hline $\mathrm{H} 4 \mathrm{a}$ & Behavioral trust positively influences the commitment of buyers and suppliers to SDPs. \\
\hline $\mathrm{H} 4 \mathrm{~b}$ & $\begin{array}{l}\text { Behavioral trust positively influences the perception that there are fewer risks involved } \\
\text { in business relationships between companies linked to SDPs. }\end{array}$ \\
\hline $\mathrm{H} 5 \mathrm{a}$ & Cognitive trust positively influences the commitment of buyers and suppliers to SDPs. \\
\hline H5b & $\begin{array}{l}\text { Cognitive trust positively influences the perception that there are fewer risks involved in } \\
\text { business relationships between companies linked to SDPs. }\end{array}$ \\
\hline
\end{tabular}

Source: Authors' own elaboration.

\subsection{Methodological procedure}

This research, which can be characterized as quantitative, descriptive and crosssectional (Hair et al., 2009), had as its field of study the Supplier Development Programs. The target population was composed of professionals from buying companies and suppliers companies linked to the SDPs of any State of Brazil.

Since the universe of participants of the SDPs is not completely known, due to the existence of several programs without connection between them (it is estimated that thousands of companies participate in this type of program), we defined that the sampling method adopted would be the non-probabilistic method for accessibility (Hair et al., 2009). Non-probabilistic sampling, although they do not confirm behaviors, are useful to show them, enough to respond to the purpose of this research. Thus, the design adopted in this research is presented in Figure 2. 


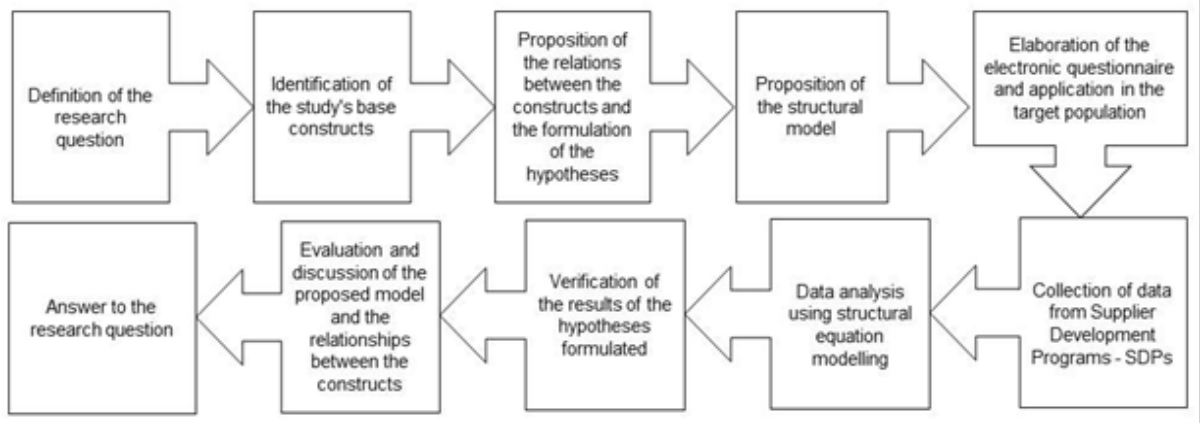

Figure 2. Flowchart of applied methodology. Source: Authors' own elaboration.

For the execution of the research, we established the use of primary data, to collect the opinions directly from the professionals of the companies linked to the SDPs. For this purpose, we constructed an electronic questionnaire with a total of 36 questions, selfadministered (the completion by the respondent itself broadens the scope of the research, since it releases the researcher from being present to apply the questionnaire), containing adapted assertions of trust constructs (Terres et al., 2009), risco total (HorMeyll, 2004), commitment (Viana et al., 1999) e satisfação (Larán \& Rossi, 2003).

The questionnaire elaborated had an initial control question whose purpose was to identify whether or not the respondent's company was linked to some Supplier Development Program in order to, determine whether the respondent would enter the survey. Based on this question, we excluded three completed questionnaires. The second question made it possible to differentiate the respondents between buying companies and supplier companies. The third question asked about the federation unit where the respondent's company was located, which allowed the grouping according to the regions of the country. The results of these two questions are presented in Table 2.

The following questions, from the 4th to the 31 st, which formed the main block of the questionnaire, were composed of statements related to the constructs (see Appendix). These questions were structured to be answered on a Likert ordinal scale (Likert, 1932) of 5 levels, so that the respondent could attribute their degree of disagreement or agreement with each statement, with level 1 being applied to total disagreement and level 5 to total agreement. It should be noted that, according to Hair et al. (2009), ordinal scales, as proposed by Likert (1932), only offer options in order of importance (in this case, agreement), being usually used to measure perceptions in psychometric studies (as it is the case of this study, being then the scale of measurement appropriate for this research).

Questions 4 to 14 involved the constructs of affective trust (from 4 to 7 ), behavioral trust (from 8 to 10) and cognitive trust (from 11 to 14), all being adapted from Terres et al. (2009), aiming to evaluate the trust of the respondents in the performance of the Supplier Development Programs. Questions 15 to 18, adapted from the total risk construct (Hor-Meyll, 2004), assessed respondents' perception of risk mitigation when conducting business with companies associated with such programs. It should be noted that the total risk construct measures the perception of risk in a generic way, without specifying a type of risk.

The following questions, from 19 to 25, adapted from Viana et al. (1999), measured the commitment construct, aiming at evaluating the involvement and commitment with the programs. The last construct, satisfaction, was evaluated in questions 26 to 31 adapted from Larán \& Rossi (2003) and, in general, sought to evaluate the respondent's satisfaction with the fact that their company - buyer or supplier - is linked to an SDP. At the end we 
added 5 questions that aimed to raise the profile of the respondent regarding gender, age, schooling, function and income, and these data were analyzed only in proportions of responses, not being part of the main analysis (structural model). The intention was exclusively to observe the presence of some sociodemographic bias in the sample.

Prior to the effective application of the questionnaire, which was built using an online platform, it went through a pre-test phase, being answered by 29 people who critically evaluated each of the questions. After the mentioned considerations, the final version was reached and we started the data collection phase, carried out through the sending of the questionnaire to more than 500 e-mails from buying and supplying companies, for the dissemination in social networks (Facebook and Linkedln) and distribution in messaging application (WhatsApp), between August / 2017 and February / 2018, reaching a total of 606 respondents, except for the 3 excluded questionnaires. In order to reach the buyer and suppliers companies that were the target of the research, we counted on the support of the SDPs from Espírito Santo, Maranhão and Pará, already mentioned, as well as the federations of state industries, which triggered the questionnaire for companies linked to the programs in their Member States, allowing to cover practically all the SDPs of Brazil.

Table 2. Sample Classification.

\begin{tabular}{cccc}
\hline Characteristic & Detailing & Quantity & Percentage \\
\hline Company & Buyer & 171 & $28.2 \%$ \\
& Supplier & $\mathbf{4 3 5}$ & $\mathbf{7 1 . 8 \%}$ \\
\hline \multirow{2}{*}{ Region } & Total & 606 & $100.0 \%$ \\
\hline & North & 32 & $5.3 \%$ \\
\hline & Northeast & $\mathbf{3 3 7}$ & $\mathbf{5 5 . 6 \%}$ \\
\hline & South & 37 & $6.1 \%$ \\
\hline & Southeast & 127 & $21.0 \%$ \\
\hline & Midwest & 73 & $12.0 \%$ \\
\hline & Total & 606 & $100.0 \%$ \\
\hline
\end{tabular}

Total number of respondents (n): 606. Source: Research Data. Authors' own elaboration.

In Table 2, it is possible to observe that there was a predominance of supplier companies $(71.8 \%)$ as respondents, which is justifiable since SDPs have a much larger number of supplier companies linked to them than buying companies. There is also a concentration of respondents located in the Northeast region of the country (55.6\%). As for Table 3, it details the profile of the survey respondents.

Table 3. Respondents Profile.

\begin{tabular}{llcc}
\hline Characteristic & Definition & Quantity & $\begin{array}{c}\text { Percentage } \\
\%\end{array}$ \\
\hline Gender & Female & $\mathbf{3 0 6}$ & $\mathbf{5 0 . 5}$ \\
\hline & Male & 300 & 49.5 \\
\hline \multirow{2}{*}{ Age } & Total & 606 & 100.0 \\
\hline & Younger than 25 years of age & 35 & 5.8 \\
\hline & From 26 to 35 years of age & $\mathbf{2 1 6}$ & $\mathbf{3 5 . 6}$ \\
\hline & From 36 to 45 years of age & 200 & 33.0 \\
\hline
\end{tabular}


Table 3. Contined...

\begin{tabular}{|c|c|c|c|}
\hline Characteristic & Definition & Quantity & $\begin{array}{l}\text { Percentage } \\
\%\end{array}$ \\
\hline & Older than 55 years of age & 35 & 5.8 \\
\hline & Total & 606 & 100.0 \\
\hline \multirow[t]{7}{*}{ Schooling } & Elementary School & 8 & 1.3 \\
\hline & High School / Technical & 69 & 11.4 \\
\hline & Higher Education & 292 & 48.1 \\
\hline & Specialization / MBA & 204 & 33.7 \\
\hline & Master / Doctorate degree & 27 & 4.5 \\
\hline & Other & 6 & 1.0 \\
\hline & Total & 606 & 100.0 \\
\hline Position or & Technician & 95 & 15.7 \\
\hline \multirow[t]{7}{*}{ Role } & Analyst & 273 & 45.0 \\
\hline & Supervisor & 72 & 11.9 \\
\hline & Manager / Coordinator & 59 & 9.7 \\
\hline & General Manager / General Coordinator & 28 & 4.6 \\
\hline & Director / Owner & 40 & 6.6 \\
\hline & Other & 39 & 6.5 \\
\hline & Total & 606 & 100.0 \\
\hline \multirow[t]{7}{*}{ Income } & Up to 1 Minimum Wage - MW (937 BRL) & 17 & 2.8 \\
\hline & Above $1 \mathrm{MW}$ (> $937 \mathrm{BRL}$ ) till $5 \mathrm{MW}$ (4.685 BRL) & 328 & 54.1 \\
\hline & $\begin{array}{l}\text { Above } 5 \mathrm{MW} \text { (> } 4.685 \mathrm{BRL}) \text { till } 10 \mathrm{MW}(9.370 \\
\text { BRL) }\end{array}$ & 181 & 29.9 \\
\hline & $\begin{array}{l}\text { Above } 10 \mathrm{MW}(>9.370 \mathrm{BRL}) \text { till } 15 \mathrm{MW}(14.055 \\
\mathrm{BRL})\end{array}$ & 42 & 6.9 \\
\hline & $\begin{array}{l}\text { Above } 15 \mathrm{MW} \text { (> } 14.055 \mathrm{BRL}) \text { till } 20 \mathrm{MW}(18.740 \\
\text { BRL) }\end{array}$ & 20 & 3.3 \\
\hline & Above $20 \mathrm{MW}$ (>18.740 BRL) & 18 & 3.0 \\
\hline & Total & 606 & 100.0 \\
\hline
\end{tabular}

Total number of respondents (n): 606. Source: Research Data. Authors' own elaboration.

It can be seen that the sample has the following demographic profile: predominance of female respondents $(50.5 \%)$, with a majority of young adults $(35.6 \%)$ in the range between 26 and 35 years. These respondents also present a good level of education, since $48.1 \%$ are graduates and $38.2 \%$ have postgraduate degrees. Regarding income, it is observed that the majority of respondents $(86.8 \%)$ have income up to 10 minimum wages.

Among the respondents, the analysts are predominant (45.0\%). However, when considering the group of Technicians, Analysts, Supervisors and Managers, that is, those that potentially have a closer contact with the actions performed by the SDPs, the mark of $82.3 \%$ of the respondents is reached, which is favorable to the survey because it contemplates people with greater knowledge about the theme proposed in this study.

The data analysis technique used was the structural equations modeling (SEM) with partial least squares estimation (PLS), since it allows to evaluate relations of influence existing between endogenous variables and exogenous variables simultaneously. For validation of the structural model we performed the confirmatory factor analysis, technique that makes it possible to ascertain how well the measured variables represent the constructs of the study. Fornell \& Larcker (1981) define that for a construct to be valid for the hypothesis tests in SEM, some validation criteria must be met, not being enough the correlations between the indicators and constructs for validation of the construct used. These criteria are convergent and discriminant validations. 
Fornell \& Larcker (1981) and Hair et al. (2009) define that the analysis of the factor loadings of the indicators (factor loadings in the construct to which the indicators belong, when compared to the other constructs), of the average variance extracted (AVE, which must be greater than 0.5) and composite reliability (which must be greater than 0.7 ) indicates the convergent validity of the constructs, mandatory for the use of the constructs in the SEM. The discriminant validity, which indicates if a construct is truly different from the others, was verified by the matrix of factor loadings (which indicates the presence of various constructs) and by the criterion by Fornell \& Larcker (1981), which says that the square root of the AVE must be greater than the correlation between the constructs (Hair et al., 2009). Both analyzes show the discriminant validity, also mandatory for the use of the constructs in the SEM. Only after convergent and discriminant validations, the hypothesis test was performed.

\section{Results and discussion}

\subsection{Validation of the measuring model}

Initially, the factor loadings of the variables of each construct were analyzed after a confirmatory factor analysis (CFA). As prescribed by Hair et al. (2009), when the variables of a construct have high factor loadings within the construct itself, values above 0.7 , this indicates that there is convergent validity, that is, that the variables converge to their own construct. Moreover, they demonstrate discriminant validity in the comparison of each construct with the others, since no cross loadings were identified (Hair et al., 2009).

According to the factor loadings of the first CFA, the results showed two variables (CO7 and SAT2) with a low factor loading and are thus removed from the model. After the exclusion of the two variables and execution of new CFA, all factor loadings were within the recommended parameters. The results of the new CFA are detailed in Table 4.

Table 4. Factor Loadings.

\begin{tabular}{|c|c|c|c|}
\hline Construct & & Variables & $\begin{array}{l}\text { Factor } \\
\text { Loadings }\end{array}$ \\
\hline \multirow{5}{*}{$\begin{array}{l}\text { Affective } \\
\text { Trust (AT) }\end{array}$} & & & AT \\
\hline & AT1 & $\begin{array}{l}\text { I feel that the Program is interested in finding good business } \\
\text { partners for my company. }\end{array}$ & 0.89 \\
\hline & AT2 & $\begin{array}{l}\text { I feel that the Program pays attention to the needs of my } \\
\text { company. }\end{array}$ & 0.89 \\
\hline & AT3 & $\begin{array}{l}\text { I feel that if my business has a problem with a business } \\
\text { partner, the Program will always be ready to guide us. }\end{array}$ & 0.87 \\
\hline & AT4 & $\begin{array}{l}\text { I feel that the Program, despite having its own line of } \\
\text { action, takes into account what is best for my company as } \\
\text { well. }\end{array}$ & 0.89 \\
\hline \multirow{4}{*}{$\begin{array}{l}\text { Behavioral } \\
\text { Trust (BT) }\end{array}$} & & & BT \\
\hline & BT1 & $\begin{array}{l}\text { I share information openly with the Program because it will } \\
\text { not use this information inappropriately. }\end{array}$ & 0.92 \\
\hline & BT2 & $\begin{array}{l}\text { I do not question the statements of the Program about its } \\
\text { performance and competence. }\end{array}$ & 0.94 \\
\hline & BT3 & $\begin{array}{l}\text { I do not monitor possible changes, such as economic } \\
\text { changes or legislation, because I know that the Program will } \\
\text { not take advantage of these changes. }\end{array}$ & 0.91 \\
\hline
\end{tabular}


Table 4. Contined...

\begin{tabular}{|c|c|c|c|}
\hline Construct & & Variables & $\begin{array}{l}\text { Factor } \\
\text { Loadings }\end{array}$ \\
\hline \multirow{5}{*}{$\begin{array}{l}\text { Cognitive } \\
\text { Trust (CT) }\end{array}$} & & & CT \\
\hline & CT1 & $\begin{array}{l}\text { Given the history of relationship with the Program, I have } \\
\text { good reason to believe the information provided by it. }\end{array}$ & 0.86 \\
\hline & CT2 & $\begin{array}{l}\text { Given the history of relationship with the Program, I have no } \\
\text { reason to doubt its competence. }\end{array}$ & 0.88 \\
\hline & CT3 & $\begin{array}{l}\text { Given the history of relationship with the Program, I have no } \\
\text { reason to doubt its efficiency. }\end{array}$ & 0.89 \\
\hline & CT4 & $\begin{array}{l}\text { The Program constantly cares to keep its actions being } \\
\text { executed properly. }\end{array}$ & 0.88 \\
\hline \multirow{5}{*}{$\begin{array}{l}\text { Perception } \\
\text { of Less } \\
\text { Risk (PLR) }\end{array}$} & & & PLR \\
\hline & PLR1 & $\begin{array}{l}\text { In general there are not many risks in maintaining a } \\
\text { commercial relationship with companies linked to the } \\
\text { Program. }\end{array}$ & 0.88 \\
\hline & PLR2 & $\begin{array}{l}\text { Taking everything into account, maintaining a business } \\
\text { relationship with companies linked to the Program prevents } \\
\text { my company from being deceived. }\end{array}$ & 0.92 \\
\hline & PLR3 & $\begin{array}{l}\text { Considering all aspects, the commercial relationship with } \\
\text { companies linked to the Program will not cause problems for } \\
\text { my company. }\end{array}$ & 0.93 \\
\hline & PLR4 & $\begin{array}{l}\text { ) I am sure we will be satisfied buying and/or supplying for } \\
\text { companies linked to the Program. }\end{array}$ & 0.85 \\
\hline \multirow{7}{*}{$\begin{array}{l}\text { Commitme } \\
\text { nt (CO) }\end{array}$} & & & CO \\
\hline & Co1 & $\begin{array}{l}\text { Everyone in my company expects the relationship with the } \\
\text { Program to continue for a long time. }\end{array}$ & 0.89 \\
\hline & $\mathrm{CO} 2$ & $\begin{array}{l}\text { Everyone in my company expects the relationship with the } \\
\text { Program to be strengthened over time. }\end{array}$ & 0.86 \\
\hline & $\mathrm{CO} 3$ & $\begin{array}{l}\text { Everyone in my company expects to increase purchases } \\
\text { and/or sales through the Program in the future. }\end{array}$ & 0.84 \\
\hline & $\mathrm{CO} 4$ & $\begin{array}{l}\text { All of my company have been very committed in the } \\
\text { relationship with the Program. }\end{array}$ & 0.90 \\
\hline & CO5 & All of my company are committed to the Program. & 0.89 \\
\hline & $\mathrm{CO6}$ & $\begin{array}{l}\text { Our relationship with the Program could be described as a } \\
\text { partnership. }\end{array}$ & 0.87 \\
\hline \multirow{6}{*}{$\begin{array}{l}\text { Satisfactio } \\
\text { n (SAT) }\end{array}$} & & & SAT \\
\hline & SAT1 & $\begin{array}{l}\text { I am pleased with the company's decision to join the } \\
\text { Program. }\end{array}$ & 0.91 \\
\hline & SAT3 & The decision to join the Program was the most sensible. & 0.93 \\
\hline & SAT4 & I am glad my company has joined the Program. & 0.90 \\
\hline & SAT5 & $\begin{array}{l}\text { I am sure that my company did the right thing by joining the } \\
\text { Program. }\end{array}$ & 0.91 \\
\hline & SAT6 & I feel good about the company's decision to join the Program. & 0.92 \\
\hline
\end{tabular}

Total number of respondents (n): 606. Source: Research Data. Authors' own elaboration.

The convergent validity, used to indicate the convergence of the variables for a given construct, was also analyzed considering the average variance extracted (AVE) greater than 0.5 (Chin, 1998), being that all the AVE complied with the recommended. The composite reliability, another convergent validity indicator, was adequate for all constructs, indicating values higher than 0.7, as dealt by Chin (1998) and Hair et al. (2009).

On the main diagonal of the matrix presented in Table 5, the value of the correlation of the constructs with themselves (which would be equal to 1.0) was replaced by the 
square root of the AVE to facilitate the comparison of the square root of the AVE of each construct with the correlations of the construct with the other constructs. The results are shown in Table 5.

To analyze the discriminant validity, which measures the degree to which a construct is effectively distinct from the others, in addition to the previous analysis of the factor loadings, the square root of the AVE of each construct was compared with the correlations with the other constructs, following guidelines by Fornell \& Larcker (1981). The square root value of the AVE of each latent variable (diagonal of Table 5 with highlighted cells and bold font) was higher than the values of the other constructs, indicating independence between them (Hair et al., 2009). With the validated constructs, we performed the hypothesis tests of the proposed structural model.

Table 5. Correlations and statistics of latent constructs.

\begin{tabular}{|c|c|c|c|c|c|c|c|c|}
\hline \multirow{2}{*}{ Latent Constructs } & \multirow{2}{*}{ AVE } & \multirow{2}{*}{ CR } & \multicolumn{6}{|c|}{ Constructs } \\
\hline & & & AT & BT & CT & CO & PLR & SAT \\
\hline AT - Affective Trust & 0.79 & 0.94 & 0.89 & & & & & \\
\hline BT - Behavioral Trust & 0.86 & 0.95 & 0.55 & 0.92 & & & & \\
\hline CT - Cognitive Trust & 0.77 & 0.93 & 0.75 & 0.61 & 0.88 & & & \\
\hline $\mathrm{CO}$ - Commitment & 0.77 & 0.95 & 0.62 & 0.52 & 0.71 & 0.88 & & \\
\hline PLR - Perception of Less Risks & 0.80 & 0.94 & 0.59 & 0.70 & 0.69 & 0.78 & 0.90 & \\
\hline SAT - Satisfaction & 0.83 & 0.96 & 0.68 & 0.53 & 0.76 & 0.87 & 0.76 & 0.91 \\
\hline
\end{tabular}

Caption: AVE - Average Variance Extracted; CR - Compound Reliability; AT - Affective Trust; BT - Behavioral Trust; CT - Cognitive Trust; CO - Commitment; PLR - Perception of Less Risks; SAT - Satisfaction. Note: The main diagonal of the correlation matrix shows the square root values of the AVE. Source: Research Data. Authors' own elaboration.

\subsection{Analysis and discussion of results}

Figure 1 outlined the path diagram designed for this research. Through it, we try to demonstrate the relationship between the constructs proposed in the structural model, indicating which latent variables would be related to each other and how would these relationships occur (Hair et al., 2009). For the evaluation of the structural model, we analyzed the individual parametric estimates and their significance (hypothesis test), as shown in Figure 3 and detailed in Table 6 . Based on this procedure, we realized that practically all the hypotheses proposed were supported, responding to the research objective.

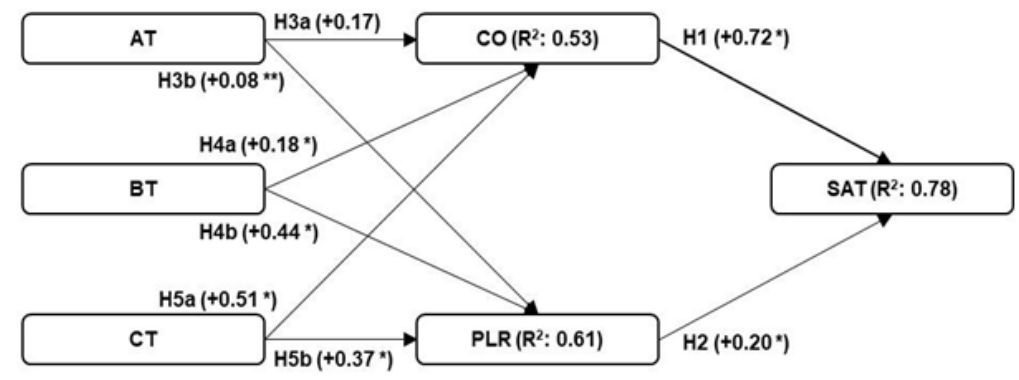

Figure 3. Proposed structural model. Caption: AT - Affective Trust; BT - Behavioral Trust; CT - Cognitive Trust; CO - Commitment; PLR - Perception of Less Risks; SAT - Satisfaction; $R^{2}$ - Coefficient of determination; * $p$-value $<0.01$; ${ }^{* *} p$-value $<0.06$. Source: Research Data. Authors' own elaboration. 
Table 6. Hypothesis Testing.

\begin{tabular}{ccccccc}
\hline Relationship & $\begin{array}{c}\text { Original } \\
\text { Sample }\end{array}$ & $\begin{array}{c}\text { Sample } \\
\text { Mean }\end{array}$ & $\begin{array}{c}\text { Standard } \\
\text { Deviation }\end{array}$ & $\begin{array}{c}\text { Standard } \\
\text { Error }\end{array}$ & T Statistics & p-value \\
\hline AT -> CO & 0.17 & 0.16 & 0.11 & 0.11 & 1.56 & 0.12 \\
\hline AT -> PLR & 0.08 & 0.07 & 0.04 & 0.04 & 1.89 & $0.06^{* *}$ \\
\hline BT -> CO & 0.12 & 0.12 & 0.04 & 0.04 & 2.89 & $0.00^{*}$ \\
\hline BT -> PLR & 0.44 & 0.44 & 0.04 & 0.04 & 9.86 & $0.00^{*}$ \\
\hline CT -> CO & 0.51 & 0.52 & 0.10 & 0.10 & 5.17 & $0.00^{*}$ \\
\hline CT -> PLR & 0.37 & 0.37 & 0.05 & 0.05 & 7.29 & $0.00^{*}$ \\
\hline CO -> SAT & 0.72 & 0.72 & 0.06 & 0.06 & 12.17 & $0.00^{*}$ \\
\hline PLR -> SAT & 0.20 & 0.20 & 0.06 & 0.06 & 3.39 & 0.00 * \\
\hline
\end{tabular}

Caption: AT - Affective Trust; BT - Behavioral Trust; CT - Cognitive Trust; CO - Commitment; PLR Perception of Less Risks; SAT - Satisfaction; ${ }^{*} p$-value $<0.01$; ${ }^{* *} p$-value $<0.06$. Source: Research Data. Authors' own elaboration.

To interpret the results, we initially analyzed whether the commitment and the perception of less risks influence the satisfaction of buyer and supplier companies with the performance of the Supplier Development Programs to which they are linked. Next, we analyze if the affective, behavioral and cognitive trusts influence the commitment and the perception of less risks. The results support most of the hypotheses suggested, giving support to the structural model. These results are then compared with the results of other studies related to the studied constructs.

In analyzing Figure 2, it is verified that both the commitment (CO) with the SDPs $(\mathrm{H} 1$ : 0.72 , $p$-value $<0.01)$, as well as the perception that there are less risks (PLR) when carrying out commercial transactions with related companies $(\mathrm{H} 2: 0.20$, $p$-value $<0.01)$, demonstrated to influence the satisfaction of the companies surveyed in $78.2 \%$. This result is in agreement with the proposed structural model. Similarly, the study by Caroço \& Correia (2012) identified that high levels of commitment have positive implications on organizational results, generating satisfaction and motivation, supporting the results achieved.

Regarding the commitment, the results show that the $\mathrm{H} 1$ hypothesis was supported, corroborating with the argument that led to the construction of the hypothesis: the more committed to the actions of the SDPs, the buying and supplying companies are, probably the more and better results they will reach over time, being more satisfied with the performance of programs. Studies have shown that commitment tends to be one of the dimensions that influence satisfaction, being considered a key variable in models of successful relationship between buyers and suppliers (Rauyruen \& Miller, 2007; Kim \& Choi, 2015).

Regarding the perception of less risks, the results show that the $\mathrm{H} 2$ hypothesis was supported. According to Hor-Meyll (2004), the perception of risk stems from the evaluation of a given situation and from that assessment it is subjectively inferred an expectation of loss, that is, the risk involved. In this sense, the mitigation of the risk element shows itself to be a strategy of competitive advantage by enabling security to commercial transactions between companies (Shi et al., 2018). Thus, the results suggest that the performance of SDPs can convey the perception that risks can be mitigated in commercial transactions involving companies linked to the programs, becoming an element that can influence the satisfaction of buyer and supplier companies (Lancastre \& Lages, 2006). 
By comparing the results, it is verified that the commitment has greater influence (effect of 0.72 ) on satisfaction than the perception of less risks (effect of 0.20 ). The results suggest that the SDPs can invest in actions that increase the commitment of the buyer and supplier companies linked to these programs with the actions they perform, so that this commitment contributes to the development and maintenance of business links between these companies, typical relationships stimulated by SDPs (Botelho \& Bourguignon, 2011). The likely result will be the participants' satisfaction with the performance of the SDPs.

Analyzing the influence of affective, behavioral and cognitive trusts on the constructs commitment and perception of less risks, we found that $52.7 \%$ of the first construct and $61.2 \%$ of the second construct are explained by the three types of trust. Again, the results are in agreement with the proposed structural model, which proposed to verify if the affective, behavioral and cognitive trusts influence the commitment and the perception of less risks.

The result of $52.7 \%$ of the commitment construct is explained by two types of trust: the behavioral and cognitive. In comparing the effect of these two influences, it is verified that cognitive trust tends to be the one that most influences the commitment. Hypothesis $\mathrm{H} 3 \mathrm{a}$, which refers to affective trust, was rejected. Referring to the study by Zur et al. (2012), affective trust is important in the initial phase of the relationship, but in the case of a long-term B2B relationship profile - of the buying and supplying companies with the SDPs - the results indicate that only the behavioral and cognitive trusts can have such influence.

Regarding behavioral trust, the hypothesis $\mathrm{H} 4 \mathrm{a}$, with effect of 0.18 ( $\mathrm{p}$-value $<0.01$ ), was supported. The results indicate that this type of trust tends to positively influence the commitment of buyer and supplier companies with the SDPs. Study has shown that relationships characterized by behavioral trust are highly valued and culminate in more desire for commitment (Lancastre \& Lages, 2006). Behavioral trust can motivate buyer and supplier companies to share information with SDPs, for evaluating that these programs will use them solely to select good trading partners and establish positive business links, which is one of the premises of these programs (Botelho \& Bourguignon, 2011).

Hypothesis $\mathrm{H} 5 \mathrm{a}$, which deals with cognitive trust, was supported, with effect of 0.51 ( $p$-value < 0.01). With the greater effect of influence on the commitment among the three types of trust, the result suggests that the knowledge of the attributes of the SDPs which, according to Terres et al. (2009), is the basis of the cognitive trust, derived from a history of relationship maintained by the buyers and suppliers with the programs to which they are linked, potentially positively influences the commitment of these companies to the performance of the programs. This involvement tends to be relevant in order to achieve high levels of satisfaction (Power et al., 2001).

The construct perception of less risk is explained in $61.2 \%$ by the three types of trust - affective, behavioral and cognitive -, since the three hypotheses were supported. Power et al. (2001) investigated the relationship of critical factors to the organization in supply chain management and affirmed that the involvement based on trust, commitment and low perception of risk is an important process for achieving high levels of satisfaction.

The results indicate that the trust of buyer and supplier companies in the performance of the SDPs leads to the perception that there are less risks involved in the commercial relations established with companies associated with these programs, influencing positively the satisfaction of these companies. A previous study indicates 
that in establishing business relationships, companies have each a perception of the maximum level of risk they accept to undergo (Marconatto et al., 2014).

As to the hypothesis $\mathrm{H} 3 \mathrm{~b}$, that affective trust positively influences the perception that there are fewer risks involved in the commercial relations between companies linked to SDPs, we obtained an effect of 0.08 ( $p$-value <0.06), supporting the hypothesis at $6 \%$. This result shows that affective trust can arouse in buyers and suppliers the feeling that SDPs are really interested in the issues that cause them to be linked, tending to the perception that there are fewer risks when establishing business links with companies associated and indicated by these programs. This feeling occurs because the affective trust is based on the belief of a company that the other part - in this case the belief that buyer and supplier companies maintain in SDPs - will perform actions that will culminate in positive results for it, in addition to not performing unexpected actions that generate negative results (Cambra-Fierro \& Polo-Redondo, 2008).

Hypothesis H4b, related to behavioral trust, was supported ( $p$-value $<0.01$ ) and presented the highest effect (0.44) on the construct perception of less risks. The results suggest that the behavioral trust resulting from the SDPs posture maintained in relationships with buyer and supplier companies, in particular with regard to the indication of trading partners meeting supply requirements (Freitas, 2009), results in the perception that there are less risks when transacting with companies linked to these programs. And as stated by Rauyruen \& Miller (2007), trust is a central building block for the development of successful relationships in $\mathrm{B} 2 \mathrm{~B}$ markets.

Regarding the hypothesis $\mathrm{H} 5 \mathrm{~b}$, according to which the cognitive trust positively influences the perception that there are less risks involved in the commercial relations between companies linked to the SDPs, was also supported ( $p$-valor $<0,01$ ), with effect of 0.37 . In the cognitive dimension, the level of trust that buyers and suppliers have with regard to SDPs tends to be based on the evaluation of issues such as competence and responsibility from the history of relationship with these programs (Terres et al., 2009). And the responsible action of SDPs to indicate good trading partners can influence the perception of buyers and suppliers that there are less risks involved in the established business relationships with companies associated with such programs.

The results suggest that to increase the satisfaction of buying and supplying companies with the performance of SDPs, it seems to be relevant to strengthen the trust placed by these companies in the programs to which they are linked, generating more commitment to the programs and the perception that there are less risks when establishing business relations with companies related to them. In order to deepen the interpretation, the effects of these three types of trust on the commitment and the perception of less risks were detailed in Table 7, constructs that have been shown to influence satisfaction.

Table 7. Summary of the effects of types of trust.

\begin{tabular}{lccc}
\hline \multirow{2}{*}{ Constructs } & \multicolumn{3}{c}{ Type of Trust } \\
\cline { 2 - 4 } & Affective & Behavioral & Cognitive \\
\hline Commitment & H3a: 0.17 & H4a: $0.18^{*}$ & H5a: $0.51^{*}$ \\
\hline $\begin{array}{l}\text { Perception of Less } \\
\text { Risks }\end{array}$ & H3b: $0.08^{* *}$ & H4b: $0.44^{*}$ & H5b: $0.377^{*}$ \\
\hline
\end{tabular}

Caption: * p-value $<0.01$; ** $p$-value $<0.06$. Source: Research Data. Authors' own elaboration. 
As can be seen in Table 7, we emphasize that the result of the relationship between commitment and affective trust showed no statistically significant relationship between the two. However, even if we considered a p-value $<0.06$, we observed a small influence of affective trust on the perception of less risks. The results indicate that affective trust, which involves the establishment of an emotional bond between the parties (Akrout et al., 2016), does not influence the commitment of buying and supplying companies with their SDPs, but it influences, even if little, the perception of less risks.

These results allow some findings. Rescuing the understanding that Supplier Development Programs play the role of service providers and buying and supplying companies play the role of consumers (Sirdeshmukh, Singh, \& Sabol, 2002), it can be assumed that affective trust does not influence the commitment of these companies to the SDPs to which they are bound because it is a type of business-to-business relationship, where rational issues, more associated with behavioral and cognitive trusts, overlap with emotional issues.

Cambra-Fierro \& Polo-Redondo (2008) argue that trust emphasizes faith in one's moral integrity and goodwill, alleviating the fear that the trading partner acts opportunistically. This is because trust results in a company's belief that its trading partner will perform actions that will culminate in positive results for themselves, in addition to not taking any unexpected actions that cause negative results. By this description, we understand why affective trust can influence, albeit to a small extent, the perception of buying and supplying companies that there are fewer risks involved in established business relationships with other companies also linked to SDPs: these companies believe in the good faith of the SDPs by indicating possible trading partners, who will probably act correctly and will not seek to take undue advantage of the business relationship.

The other results recorded in Table 7 show an interesting cross: behavioral trust has less influence on commitment and greater perception of less risks, while cognitive trust has a greater influence on the commitment and less on the perception of less risks. As mentioned earlier, cognitive trust is based on knowledge of the characteristics of the other party, such as responsibility and competence, and comes from a history of relationship (Terres et al., 2009).

This tends to explain why cognitive trust influences commitment more: the more positive is the relationship between buying and supplying companies with the SDPs to which they are linked - identifying in them characteristics as responsibility when indicating possible commercial partners and competence in the execution of their actions -, more committed to the programs tend to be those companies. On the other hand, cognitive trust seems to have less influence on the perception of less risks, which can be justified by the perception of suppliers and buyers that, despite the performance of the Supplier Development Programs, the risks are still present and rationally the SDP participants recognize this, even if they rely on the programs to which they are linked.

The lack of a history of relationship of buyers and suppliers with the SDPs to which they are linked and of a history of established commercial relationship with companies indicated by these programs values behavioral trust. Based on rational questions, as is for cognitive trust, behavioral trust stems from the observation of a coherent behavior of the parties involved in a relationship (Terres et al., 2009), that is, it can be believed that both buyer and supplier have the expectation that these programs will act in a coherent way, with a professional attitude. And the behavioral trust derived from this expectation may motivate buyer and supplier companies to share information with the 
SDPs to which they are linked, because they believe that the programs will use this information only to select good business partners, stimulating the perception that there are fewer risks when transacting with companies indicated by these programs.

The results also show that behavioral trust influences commitment less, which needs a history of relationship with outstanding positive facts to be stimulated. Finally, considering that all hypotheses linked to behavioral trust and cognitive trust were statistically validated ( $p$-value $<0.01$ ), it is worth highlighting the actions taken by the SDPs to strengthen the behavioral and cognitive trusts of buyers and suppliers, in such a way as to provide an increase in the commitment of these companies to the actions carried out by the programs and to stimulate the perception that there are fewer risks when transacting with companies also linked to them, resulting in satisfaction.

In summary, by examining the results of all the constructs studied, we found that the structural model revealed that the satisfaction of the professionals of the buying and supplying companies with the performance of the Supplier Development Programs to which they are linked tends to be influenced by the commitment of these companies to the programs and by the perception that there are fewer risks when conducting business transactions with related companies. Commitment and perception of less risks, in turn, potentially influenced by affective, behavioral and cognitive trusts that professionals from buying and supplying companies deposit in the SDPs to which they are linked, except for the influence of affective trust on the commitment. The results broaden the understanding of the factors that contribute to the satisfaction in the B2B environment, in particular in the administration of the supply chains, contributing to the improvement of the management of SDPs.

\section{Conclusion}

This study aimed to identify whether trust, in its affective components, behavioral and cognitive, influences the commitment and perception of less risks, leading to, consequently, the satisfaction of the professionals of participating companies with the performance of the SDPs to which they are linked. The results showed positive and significant relationships between the constructs commitment and perception of less risks and the satisfaction of the buyers and suppliers with the performance of the SDPs, as evidenced by this same type of relationship between affective, behavioral and cognitive trusts and the constructs commitment and perception of less risks, with the proviso that the relationship between affective trust and commitment was not significant. These findings suggest that an active role of SDPs that enhances trust, mainly behavioral and cognitive, of the professionals of the buying and supplying companies, can increase the commitment of these companies to the actions developed by the programs and stimulate the perception that there are fewer risks when transacting with related companies, resulting in the satisfaction of the participating companies.

As a theoretical contribution, this study collaborated with the knowledge about the process leading to satisfaction in the supply chain, with a focus on the satisfaction of professionals from buyers and suppliers linked to the Supplier Development Programs of the country, which act to foster business links between such companies (Botelho \& Bourguignon, 2011). The establishment of business links between buying and supplying companies requires these companies to trust the performance of the SDP to which they are linked, because it is considered a fundamental factor in the relations of partnership (Lancastre \& Lages, 2006). 
In the field of practical contribution, we hope that this research will demonstrate to the Brazilian SDPs that strengthening trust, generating commitment and perception of less risks, influences the satisfaction of the professionals of buyers and suppliers with the actions that these programs develop, enabling them to improve their performance in the search for satisfaction of these companies. And we assume that satisfaction with the performance of the SDPs can contribute to the permanence of buyers and suppliers linked to the programs and, as a consequence, for the establishment of business links, promoting the development of supply chains.

This research has some limitations. One of them is the adoption of the nonprobabilistic method for accessibility, which results in non-selected respondents by means of a statistical criterion. Therefore, the results cannot be generalized but present evidence of behavior that can be confirmed in later studies. Another limitation concerns the set of constructs adopted in this study. Although they influence the satisfaction of the professionals of the companies surveyed, we infer that there are other factors that may also influence the satisfaction of these professionals.

In this context, we suggest that future research investigate new constructs, such as a construct associated to the formation of networks of relationships, being possibly influenced by affective trust, or repeat this study after a certain period of time, to serve as a comparison with the results found here, considering changes in the Brazilian economic, political and legal scenarios. Finally, we can understand the expectations of the buying and supplying companies linked to SDPs, considering the importance of the continuity of studies on these expectations in order to promote new academic contributions, of market and social, in such a way that this reflects in a better performance of the Programs of Development of Suppliers of all Brazil, favoring buying and supplying companies and the business environment in general, generating jobs and income.

\section{Acknowledgements}

This research was supported by Brazilian National Council for Scientific and Technological Development (CNPq/Brazil), project 304209/2018-0, by Foundation for Research Support of Espírito Santo (FAPES/Brazil), projects 84513772 (599/2018) and 85395650 (228/2019), by Portuguese Science Foundation (FCT/Portugal) through NECE (Núcleo de Estudos em Ciências Empresariais), project UID/GES/04630/2019, and by IFTS (Instituto Fucape de Tecnologias Sociais), project 2018-2021.

\section{References}

Akrout, H., Diallo, M. F., Akrout, W., \& Chandon, J. L. (2016). Affective trust in buyer-seller relationships: a two-dimensional scale. Journal of Business and Industrial Marketing, 31(2), 260-273. http://dx.doi.org/10.1108/JBIM-11-2014-0223.

Beitelspacher, L. S., Baker, T. L., Rapp, A., \& Grewal, D. (2018). Understanding the long-term implications of retailer returns in business-to-business relationships. Journal of the Academy of Marketing Science, 46(2), 252-272. http://dx.doi.org/10.1007/s11747-0170553-6.

Borella, M. R. C., Barcellos, P. F. P., Sachdev, H., Merx, G. R., \& Galelle, A. (2017). Estrutura organizacional, capacidade dos serviços e impacto sobre o desempenho de fornecedores logísticos no contexto B2B. Gestão \& Produção, 24(2), 335-369.

http://dx.doi.org/10.1590/0104-530x1538-16. 
Bortolotti, S. L. V., Moreira, F. S., Jr., Bornia, A. C., Sousa, A. F. S., Jr., \& Andrade, D. F. (2012). Avaliação do nível de satisfação de alunos de uma instituição de ensino superior: uma aplicação da Teoria da Resposta ao Item. Gestão \& Produção, 19(2), 287-302. http://dx.doi.org/10.1590/S0104-530X2012000200005.

Botelho, D., \& Bourguignon, M. F. M. (2011). Fostering linkages between transnational corporations and small to medium-sized enterprises in Brazil. BAR - Brazilian Administration Review, 8(3), 247-265. http://dx.doi.org/10.1590/S180776922011000300003.

Cambra-Fierro, J. J., \& Polo-Redondo, Y. (2008). Creating satisfaction in the demand-supply chain: the buyers' perspective. Supply Chain Management, 13(3), 211-224. http://dx.doi.org/10.1108/13598540810871253.

Campos, R. M., Mesquita, J. M. C., \& Martins, H. C. (2015). Análise dos impactos do tratamento de reclamações sobre a satisfação e lealdade de clientes: estudo em uma empresa do setor da saúde. Gestão \& Planejamento, 16(2), 149-164.

Capioto, G. R., Barbosa, D. H., Kurumoto, J. S., \& Cotrim, S. L. (2019). Suppliers' network analysis under the perspective of structural, relational and cognitive embeddedness: an exploratory study. Production, 29(1), 1-15. http://dx.doi.org/10.1590/0103-6513.20180041.

Caroço, J. G., \& Correia, M. F. (2012). Práticas de gestão de recursos humanos e satisfação no trabalho: papel mediador da motivação e comprometimento organizacional. Organizações e Trabalho, 37, 41-60.

Chin, W. W. (1998). The partial least squares approach to structural equation modeling. Modern Methods for Business Research, 295(2), 295-336.

Confederação Nacional da Indústria - CNI. (2017). Relatório anual SESI-SENAI-IEL 2016 / Serviço Social da Indústria, Serviço Nacional de Aprendizagem Industrial, Instituto Euvaldo Lodi. Brasília: SESI.

Devlin, A. G., Elmaghraby, W., \& Hamilton, R. W. (2018). Why do suppliers choose wholesale price contracts? End-of-season payments disincentivize retailer marketing effort. Journal of the Academy of Marketing Science, 46(2), 212-233. http://dx.doi.org/10.1007/s11747-0170550-9.

Dowell, D., Morrison, M., \& Heffernan, T. (2015). The changing importance of affective trust and cognitive trust across the relationship lifecycle: a study of business-to-business relationships. Industrial Marketing Management, 44, 119-130. http://dx.doi.org/10.1016/j.indmarman.2014.10.016.

Fornell, C., \& Larcker, D. F. (1981). Evaluating structural equation models with unobservable variables and measurement error. JMR, Journal of Marketing Research, 18(1), 39-50. http://dx.doi.org/10.1177/002224378101800104.

Freitas, D. V. (2009). PDF - Programa de Desenvolvimento de Fornecedores: uma estratégia de sucesso. Vitória: SEBRAE.

Gonçalo, T. E. E., \& Alencar, L. H. (2014). A supplier selection model based on classifying its strategic impact for a company's business results. Pesquisa Operacional, 34(2), 347-369. http://dx.doi.org/10.1590/0101-7438.2014.034.02.0347.

Hair, J. F., Jr., Babin, B., Money, A. H., \& Samouel, P. (2009). Fundamentos de Métodos de Pesquisa em Administração. São Paulo: Bookman Companhia.

Hor-Meyll, L. F. (2004). Construção de uma escala para mensurar o risco percebido na compra online de um serviço hoteleiro. In Anais do Encontro Anual da Associação Brasileira dos Programas de Pós-Graduação em Administração. Maringá: ANPAD.

Kim, Y., \& Choi, T. Y. (2015). Deep, sticky, transient, and gracious: an expanded buyersupplier relationship typology. The Journal of Supply Chain Management, 51(3), 61-86. http://dx.doi.org/10.1111/jscm.12081. 
König, T. C., \& Duarte, P. C. (2014). Modelo de König para medir a satisfação e fidelização dos clientes através da logística reversa de pós-venda: aplicação em uma concessionária de veículos em Joinville/SC. Produto \& Produção, 15(2), 66-87. http://dx.doi.org/10.22456/1983-8026.33572.

Lancastre, A., \& Lages, L. F. (2006). The relationship between buyer and a B2B e-marketplace: cooperation determinants in an electronic market context. Industrial Marketing Management, 35(6), 774-789. http://dx.doi.org/10.1016/j.indmarman.2005.03.011.

Lanzolla, G., \& Frankort, H. T. W. (2016). The online shadow of offline signals: which sellers get contacted in online B2B marketplaces? Academy of Management Journal, 59(1), 207-231. http://dx.doi.org/10.5465/amj.2014.0051.

Larán, J. A., \& Rossi, C. A. V. (2003). O poder da surpresa no processo emocional de formação da satisfação. In Anais do Encontro Anual da Associação Brasileira dos Programas de Pós-Graduação em Administração. Maringá: ANPAD.

Marconatto, D. A. B., Estivalete, V., \& Pedrozo, E. A. (2014). Confiança, controles e riscos em relacionamentos interorganizacionais no âmbito de cadeias de suprimentos. Revista de Administração da UFSM, 7(4), 700-718. http://dx.doi.org/10.5902/1983465917208.

Likert, R. (1932). A technique for the measurement of attitudes. Archives de Psychologie, 140, 44-53.

Nagati, H., \& Rebolledo, C. (2013). Supplier development efforts: the suppliers' point of view. Industrial Marketing Management, 42(2), 180-188. http://dx.doi.org/10.1016/j.indmarman.2012.12.006.

Narayanan, A., \& Moritz, B. B. (2015). Decision making and cognition in multi-echelon supply chains: an experimental study. Production and Operations Management, 24(8), 1216-1234. http://dx.doi.org/10.1111/poms.12343.

Parayitam, S., \& Dooley, R. S. (2009). The interplay between cognitive-and affective conflict and cognition-and affect-based trust in influencing decision outcomes. Journal of Business Research, 62(8), 789-796. http://dx.doi.org/10.1016/j.jbusres.2008.02.006.

Power, D. J., Sohal, A. S., \& Rahman, S. (2001). Critical success factors in agile supply chain management. An empirical study. International Journal of Physical Distribution \& Logistics Management, 31(4), 247-265. http://dx.doi.org/10.1108/09600030110394923.

Rauyruen, P., \& Miller, K. E. (2007). Relationship quality as a predictor of B2B customer loyalty. Journal of Business Research, 60(1), 21-31. http://dx.doi.org/10.1016/j.jbusres.2005.11.006.

Shi, Y., Lim, J. M., Weitz, B. A., \& France, S. L. (2018). The impact of retail format diversification on retailers' financial performance. Journal of the Academy of Marketing Science, 46(1), 147-167. http://dx.doi.org/10.1007/s11747-017-0559-0.

Sirdeshmukh, D., Singh, J., \& Sabol, B. (2002). Consumer trust, value, and loyalty in relational exchanges. Journal of Marketing, 66(1), 15-37. http://dx.doi.org/10.1509/jmkg.66.1.15.18449.

Skippari, M., Laukkanen, M., \& Salo, J. (2017). Cognitive barriers to collaborative innovation generation in supply chain relationships. Industrial Marketing Management, 62, 108-117. http://dx.doi.org/10.1016/j.indmarman.2016.08.002.

Terres, M. S., Santos, C. P., \& Alves, D. A. (2009). Desenvolvimento de uma escala para mensuração das confianças cognitiva, afetiva e comportamental e verificação de seus impactos na lealdade. In Anais do Encontro Anual da Associação Brasileira dos Programas de Pós-Graduação em Administração. Maringá: ANPAD.

Viana, J. C., \& Alencar, L. H. (2012). Metodologias para seleção de fornecedores: uma revisão da literatura. Produção, 22(4), 625-636. http://dx.doi.org/10.1590/S010365132012005000067. 
Viana, D. A., Cunha, M. V. M., Jr., \& Slongo, L. A. (1999). Medindo o conceito de marketing de relacionamento no contexto brasileiro: a validação de uma escala no setor industrial. In Anais do Encontro Anual da Associação Brasileira dos Programas de Pós-Graduação em Administração. Maringá: ANPAD.

Yawar, S. A., \& Seuring, S. (2018). The role of supplier development in managing social and societal issues in supply chains. Journal of Cleaner Production, 182, 227-237. http://dx.doi.org/10.1016/j.jclepro.2018.01.234.

Zur, A., Leckie, C., \& Webster, C. M. (2012). Cognitive and affective trust between Australian exporters and their overseas buyers. Australasian Marketing Journal, 20(1), 73-79. http://dx.doi.org/10.1016/j.ausmj.2011.08.001. 
Appendix. Constructs and affirmations.

\begin{tabular}{|c|c|c|}
\hline Construct & Reference & Affirmation \\
\hline \multirow[t]{4}{*}{ Affective Trust } & $\begin{array}{l}\text { Terres et al. } \\
\qquad(2009)\end{array}$ & $\begin{array}{l}\text { 4) I feel that the Program is interested in finding } \\
\text { good business partners for my company. }\end{array}$ \\
\hline & & $\begin{array}{l}\text { 5) I feel that the Program pays attention to the needs } \\
\text { of my company. }\end{array}$ \\
\hline & & $\begin{array}{l}\text { 6) I feel that if my business has a problem with a } \\
\text { business partner, the Program will always be ready } \\
\text { to guide us. }\end{array}$ \\
\hline & & $\begin{array}{l}\text { 7) I feel that the Program, despite having its own line } \\
\text { of action, takes into account what is best for my } \\
\text { company as well. }\end{array}$ \\
\hline \multirow[t]{3}{*}{ Behavioral Trust } & $\begin{array}{l}\text { Terres et al. } \\
\qquad(2009)\end{array}$ & $\begin{array}{l}\text { 8) I share information openly with the Program } \\
\text { because it will not use this information } \\
\text { inappropriately. }\end{array}$ \\
\hline & & $\begin{array}{l}\text { 9) I do not question the statements of the Program } \\
\text { about its performance and competence. }\end{array}$ \\
\hline & & $\begin{array}{l}\text { 10) I do not monitor possible changes, such as } \\
\text { economic changes or legislation, because I know } \\
\text { that the Program will not take advantage of these } \\
\text { changes. }\end{array}$ \\
\hline \multirow[t]{4}{*}{ Cognitive Trust } & $\begin{array}{l}\text { Terres et al. } \\
\qquad(2009)\end{array}$ & $\begin{array}{l}\text { 11) Given the history of relationship with the } \\
\text { Program, I have good reason to believe the } \\
\text { information provided by it. }\end{array}$ \\
\hline & & $\begin{array}{l}\text { 12) Given the history of relationship with the } \\
\text { Program, I have no reason to doubt its competence. }\end{array}$ \\
\hline & & $\begin{array}{l}\text { 13) Given the history of relationship with the } \\
\text { Program, I have no reason to doubt its efficiency. }\end{array}$ \\
\hline & & $\begin{array}{l}\text { 14) The Program constantly cares to keep its } \\
\text { actions being executed properly. }\end{array}$ \\
\hline \multirow[t]{4}{*}{$\begin{array}{l}\text { Perception of } \\
\text { Less Risks }\end{array}$} & $\begin{array}{l}\text { Hor-Meyll } \\
(2004)\end{array}$ & $\begin{array}{l}\text { 15) In general there are not many risks in } \\
\text { maintaining a commercial relationship with } \\
\text { companies linked to the Program. }\end{array}$ \\
\hline & & $\begin{array}{l}\text { 16) Taking everything into account, maintaining a } \\
\text { business relationship with companies linked to the } \\
\text { Program prevents my company from being } \\
\text { deceived. }\end{array}$ \\
\hline & & $\begin{array}{l}\text { 17) Considering all aspects, the commercial } \\
\text { relationship with companies linked to the Program } \\
\text { will not cause problems for my company. }\end{array}$ \\
\hline & & $\begin{array}{l}\text { 18) I am sure we will be satisfied buying and/or } \\
\text { supplying for companies linked to the Program. }\end{array}$ \\
\hline Commitment & $\begin{array}{l}\text { Viana et al. } \\
\text { (1999) }\end{array}$ & $\begin{array}{l}\text { 19) Everyone in my company expects the } \\
\text { relationship with the Program to continue for a long } \\
\text { time. }\end{array}$ \\
\hline
\end{tabular}




\begin{tabular}{|c|c|c|}
\hline \multirow[t]{7}{*}{ Construct } & Reference & Affirmation \\
\hline & & $\begin{array}{l}\text { 20) Everyone in my company expects the } \\
\text { relationship with the Program to be strengthened } \\
\text { over time. }\end{array}$ \\
\hline & & $\begin{array}{l}\text { 21) Everyone in my company expects to increase } \\
\text { purchases and/or sales through the Program in the } \\
\text { future. }\end{array}$ \\
\hline & & $\begin{array}{l}\text { 22) All of my company are willing to allocate } \\
\text { considerable effort and investment in strengthening } \\
\text { the relationship with the Program. }\end{array}$ \\
\hline & & $\begin{array}{l}\text { 23) All of my company have been very committed in } \\
\text { the relationship with the Program. }\end{array}$ \\
\hline & & $\begin{array}{l}\text { 24) All of my company are committed to the } \\
\text { Program. }\end{array}$ \\
\hline & & $\begin{array}{l}\text { 25) Our relationship with the Program could be } \\
\text { described as a partnership. }\end{array}$ \\
\hline \multirow[t]{6}{*}{ Satisfaction } & $\begin{array}{l}\text { Larán \& Rossi } \\
\qquad(2003)\end{array}$ & $\begin{array}{l}\text { 26) I am pleased with the company's decision to join } \\
\text { the Program. }\end{array}$ \\
\hline & & $\begin{array}{l}\text { 27) Being tied to the Program is exactly what the } \\
\text { company needs to expand its business } \\
\text { relationships. }\end{array}$ \\
\hline & & $\begin{array}{l}\text { 28) The decision to join the Program was the most } \\
\text { sensible. }\end{array}$ \\
\hline & & 29) I am glad my company has joined the Program. \\
\hline & & $\begin{array}{l}\text { 30) I am sure that my company did the right thing by } \\
\text { joining the Program. }\end{array}$ \\
\hline & & $\begin{array}{l}\text { 31) I feel good about the company's decision to join } \\
\text { the Program. }\end{array}$ \\
\hline
\end{tabular}

Source: Adapted from validated scales by Terres et al. (2009), Hor-Meyll (2004), Viana et al. (1999), and Larán \& Rossi (2003). 